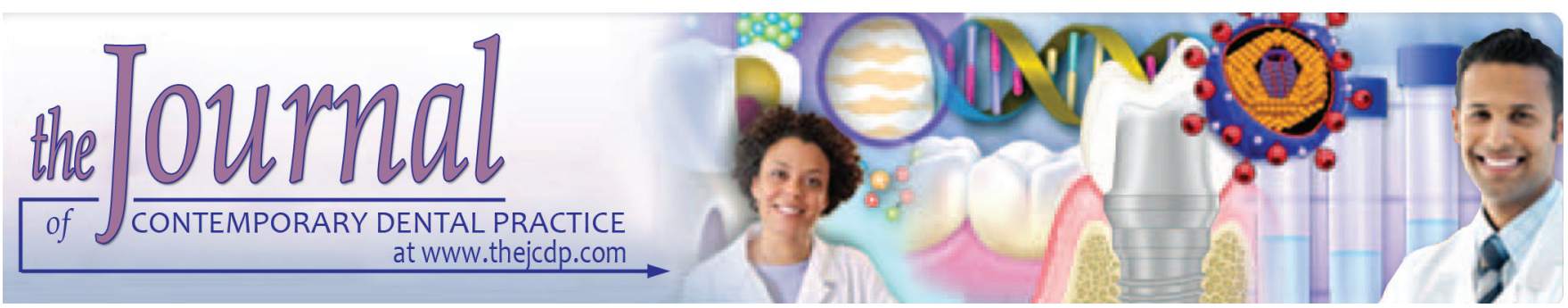

\title{
Surface Characterization and Cell Adhesion of Different Zirconia Treatments: An in vitro Study
}

\author{
${ }^{1}$ Wadih Nassif, ${ }^{2}$ Mohamad Rifai
}

\section{ABSTRACT}

Aim: The aim of this study was to characterize the surface of zirconia subjected to different treatments and evaluate its effect on cell adhesion and proliferation.

Materials and methods: A total of 80 zirconia disks were divided into four groups ( $n=20$ ) according to the surface treatments used: group I: as-sintered (AS), no surface treatment applied; group II: abrasion treatment applied using Rocatec (ROC; 3M ESPE) system with silica-coated alumina powder of grit size $110 \mu \mathrm{m}$; group III: erbium, chromium:yttrium, scandium, gallium, garnet (Er, Cr:YSGG) laser (LAS; BIOLASE) was used at a frequency of $20 \mathrm{~Hz}$ and output power of $3 \mathrm{~W}$; and group IV: specimens were subjected to the selective infiltration etching (SIE) technique. Surface characterization was evaluated for the different groups (roughness, hardness, and morphology), and cell behavior (adhesion and proliferation) was tested ( $\alpha=0.05$ ).

Results: The ROC group reported a significant increase in surface roughness $(2.201 \pm 0.352)$ and Vickers hardness $(1758 \pm 16.6)$ compared with the other surface treatments. The SIE surface-treated group reported a significantly higher number of cells ( $64.5 \pm 2.6$ and $53.5 \pm 2.2$ respectively) compared with the other surface-treated groups.

Conclusion: The SIE is a promising surface treatment for zirconia that significantly enhances cell adhesion and osseointegration.

Clinical significance: The SIE treatment of zirconia implants may help in a faster and better osseointegration.

Keywords: Cell adhesion, Surface treatment, Zirconia.

How to cite this article: NassifW, Rifai M. Surface Characterization and Cell Adhesion of Different Zirconia Treatments: An in vitro Study. J Contemp Dent Pract 2018;19(2):181-188.

\footnotetext{
1,2Department of Prosthodontics, Faculty of Dental Medicine Lebanese University, Beirut, Lebanon
}

Corresponding Author: Wadih Nassif, Department of Prosthodontics, Faculty of Dental Medicine, Lebanese University, Beirut, Lebanon, Phone: +9613686787, e-mail: dr.wadihnassif@hotmail.com

\section{Source of support: Nil}

\section{Conflict of interest: None}

\section{INTRODUCTION}

Among the major developments in dentistry are the introduction of engineering and computer software in the form of computer-aided design and computer-aided manufacturing (CAD/CAM) to construct prosthetic restorations. The CAD/CAM technology allows the introduction of new generations of ceramic-based materials, such as tetragonal zirconia polycrystal (TZP), which has highly favorable mechanical properties. ${ }^{1-4}$ Several studies have reported that zirconia has a high biocompatibility and long-term osseointegration when used as dental implants with a bone-to-implant contact similar to that of titanium. ${ }^{1,5}$

The three phases of zirconia, monoclinic (M), cubic $(\mathrm{C})$, and tetragonal $(\mathrm{T})$, are temperature dependent. Stabilization of the fragile monoclinic phase is required to avoid a transformation from tetragonal to monoclinic phases in usual applications. ${ }^{6,7}$

The transformation toughening mechanism, following a stress induced on zirconia, improves its mechanical properties making it suitable as an implant material. ${ }^{8}$ The reported properties of yttria-stabilized TZP (Y-TZP) and mainly its biocompatibility and biological-related responses make it a potential titanium alternative. ${ }^{1,2,9}$ Studies have shown a low-temperature degradation of zirconia to be due to the phase transformation from the $\mathrm{T}$ to $\mathrm{M}$ phases under stress or wet conditions. ${ }^{10}$

The zirconia surface, due to its chemical inertness, is resistant to strong acids, such as hydrofluoric acid, ${ }^{11}$ or organic and inorganic dissolving agents. Published papers have shown that establishing a chemical bond with zirconia is difficult, which open the door to investigations on different surface treatments. ${ }^{12-16}$ Zirconia 
surface treatments induced a change in the structure and topography of the dental implants, enhancing bone apposition at the interface. ${ }^{17}$

The osseointegration of an implant material is determined by the surface characteristics of the material, such as surface chemistry, surface charge, bulk material rigidity, and roughness. These characteristics influence the cell adhesion and proliferation to the zirconia material. ${ }^{18}$ Optimal cell adhesion is, in turn, a prerequisite for the proliferation and differentiation of anchorage-dependent cells like bone cells, and for the stable integration of an implant into the surrounding tissue. ${ }^{19,20}$ It was clearly reported that surface roughness has a significant impact on cell behavior at the material interface. ${ }^{21}$

Papers have reported that the osteoblasts adhesion on rough surfaces is significantly higher than on smooth ones; the surface-roughened zirconia implants showed five-fold more removal torque when compared with the machined ones. ${ }^{22,23}$ The collagen fiber behaviors around the dental implant neck are similar in vivo and independent from materials used ( $\mathrm{Ti}$ or $\mathrm{Zr}$ ); the surface topography is found influencing cell attachment, adhesion, proliferation, and differentiation ${ }^{24}$ and also cell orientation and migration. ${ }^{25}$

The correlation between cellular activity and the surface roughness of materials remains unclear; a recent paper $^{26}$ indicates that zirconia surface-containing niobium oxide provides appropriate surface condition for osseointegration at the fixture level and for peri-implant mucosal sealing at the abutment level, producing a suitable candidate for dental implantation with an expected favorable clinical outcome. A paper evaluating the influence of a nanoporous zirconia implant surfaces showed that they favored cell growth and attachment compared with the polished surface. ${ }^{17}$

The aim of this study was to evaluate the effect of different zirconia surface treatments on cell adhesion and proliferation. The null hypotheses tested were that surface treatment has no effect on cell adhesion and proliferation on treated zirconia surface.

\section{MATERIALS AND METHODS}

\section{Specimen Preparation}

A total of 80 zirconia disks (3 mm thick and $19.5 \mathrm{~mm}$ diameter) were fabricated by milling presintered blocks (ZI, Amanngirrbach, Austria) using a CAD/CAM device (Ceramill motion 2, Amanngirrbach, Austria). Then, the disks were sintered (Ceramill Therm, Amanngirrbach) (Table 1). The sintered disks were polished using ascending grit silicon carbide polishing paper in a rotating polishing device (Ecomet, Buehler, Germany) under water
Table 1: Zirconia properties: Ceramill ZI (AS)

\begin{tabular}{ll}
\hline Chemical composition & $\mathrm{ZrO}_{2}+\mathrm{HfO}_{2}+\mathrm{Y}_{2} \mathrm{O}_{3}:>99.0$ \\
& $\mathrm{Y}_{2} \mathrm{O}_{3}: 4.5-5.6$ \\
& $\mathrm{HfO}_{2}:<5 \mathrm{Al}_{2} \mathrm{O}_{3}:<0.5$ \\
& Other oxides: $<0.5$ \\
& $>6.05 \mathrm{~g} / \mathrm{cm}^{3}$ \\
Density & $10.5 \times 10^{-6}$ \\
Thermal expansion coefficient & $>1,200 \mathrm{MPa}$ \\
Flexure strength & $2,000 \mathrm{MPa}$ \\
Compressive strength & $>200 \mathrm{GPa}$ \\
Elastic modulus & $115000 \mathrm{HV} 0.1$ \\
Hardness & Partially stabilized tetragonal \\
Crystal structure & zirconium oxide \\
& $<0.06 \mu \mathrm{m}$ \\
Crystal size & Amanngirrbach, Austria \\
Manufacturer & Cylindrical blocks of three \\
Supply form & different sizes \\
Sintering shrinkage & $20 \%$ \\
Sintering cycle & $1350^{\circ} \mathrm{C}$ for $6-10$ hours \\
Color & Pure white \\
\hline
\end{tabular}

cooling and a fixed load. The specimens were divided into four groups of 20 each $(n=20)$ :

- Group I: As-sintered (control), the specimens in this group are not subjected to any surface treatment.

- Group II: Uniform tribochemical abrasion treatment was conducted [Rocatec (ROC), 3M ESPE, Seefeld, Germany] plus silica-coated alumina powder of grit size $110 \mu \mathrm{m}$ for 60 seconds, with a pressure of $300 \mathrm{kPa}$ at a perpendicular position $10 \mathrm{~mm}$ away. The specimens are cleaned in an ultrasonic bath for 10 minutes in absolute ethanol, then left to dry at room temperature.

- Group III: The zirconia specimen's surfaces were irradiated using an Er, Cr:YSGG laser (BIOLASE, California, USA); the laser was operated at a frequency of $20 \mathrm{~Hz}$, the output power at $3 \mathrm{~W}$, and the optical fiber was placed at a distance of $10 \mathrm{~mm}$. The water/air flow was $85 \% / 75 \%$ respectively, used continuously during the irradiations.

- Group IV: The zirconia specimen surface was subjected to the SIE as described by Aboushelib et al. ${ }^{12}$ This technique will transform the dense and nonbonding surface of zirconia into a highly retentive surface through the establishment of intergrain nanoporosity. On a micro level, the grains of zirconia are subjected to nano-rearrangement movements, splitting, and sliding in the presence of other phases and when heated to a sufficient temperature.

\section{Surface Characterization}

\section{Roughness Analysis}

The surface roughness of the disks was measured using a traveling contact probe (S-J 400; Mitutoyo Corp, Tokyo, 
Japan) with a measuring length of $4 \mathrm{~mm}$ and cutoff value of $0.8 \mathrm{~mm}$. The specimens were then observed with an electron-beam three-dimensional (3D) surface roughness analyzer (ERA-8900FE; Elionix, Tokyo, Japan) at an accelerating voltage of $15 \mathrm{kV}$, and 3D images reconstructed within a dimensional range of $60 \times 45 \mu \mathrm{m}$. Two perpendicular measurements were performed for each specimen. The arithmetic mean roughness ( $\mathrm{Ra}$ ) and the maximum profile height $(\mathrm{Rz})$ were measured in $\mu \mathrm{m}$ and correlated with the strength data.

\section{Vickers Microhardness Test}

The Vickers hardness number (VHN) test was performed with a microhardness tester (Shimadzu HMV; Shimadzu Corporation, Tokyo, Japan) with 200 gm of load application for 15 seconds. Three indentations were taken for each of the top and the bottom surfaces of each resin cement specimen. These indentations were not closer than $1 \mathrm{~mm}$ to the margin and were averaged to determine the hardness value for each specimen. The VHN was the quotient obtained by dividing the load by square area of indentation: $\mathrm{HV}=\mathrm{F} / \mathrm{d}^{2}$ where $\mathrm{F}$ is the load in kilograms and $\mathrm{d}^{2}$ the arithmetic mean of the two diagonals, $\mathrm{d} 1$ and $\mathrm{d} 2$ in $\mathrm{mm}$.

\section{Surface Nanoroughness}

The surface morphology and topography were evaluated with an atomic force microscope (AFM, Agilent, 5420, USA); a surface 3D imaging was collected in contact mode.

\section{Scanning Electron Microscopy}

The specimens were attached to aluminum stubs, carbon coated, and viewed under the scanning electron microscope (SEM; SERON AIS2100, Korea). Scanning electron micrographs of the different material microstructural components at different magnifications in backscatter electron mode were captured.

\section{Statistical Analysis}

Data were statistically analyzed using Statistical Package for the Social Sciences software (SPSS version 15.0, SPSS, Inc., Chicago, Illinois). The Kolmogorov-Smirnov test was used to verify the normality of the data distribution. The one-way analysis of variance (ANOVA) was used and Tukey's post hoc test for multiple comparisons; $\mathrm{p}$ was set to 0.05 for all statistical tests.

\section{Cell Adhesion and Proliferation}

\section{Cell Thawing}

The cell line used was the Saos-2 ("Sarcoma osteogenic" that is derived from the primary osteosarcoma of an 11-year-old Caucasian girl in 1973). The vials were placed directly in a waterbath at $37^{\circ} \mathrm{C}$ (to induce heat shock). Then, the cells were washed with complete media, centrifuged at $1000 \mathrm{rpm}$ for 5 minutes, then resuspended with new fresh media, and transferred to flasks for culture.

\section{Cell Culture}

Saos- 2 cells were cultured in a Dulbecco's Modified Eagle Medium, (Sigma-Aldrich, Germany) containing $10 \%$ fetal bovine serum, supplemented with penicillin and streptomycin (1\%), and maintained in a humidified incubator (HEPA class 100 Model 121; Thermo Electric Corporation, West Chester, PA) at $37^{\circ} \mathrm{C}$, in the presence of $5 \% \mathrm{CO}_{2}$, for 1 week. When the cell monolayer became confluent, culture medium was removed and cells were washed with PBS. Then, cells were detached from the tissue culture flask with $2 \mathrm{~mL}$ of trypsin (1X)-ethylenediaminetetraacetic acid (Sigma-Aldrich) solution and maintained in a humidified incubator at $37^{\circ} \mathrm{C}$, in the presence of $5 \% \mathrm{CO}_{2}$ for approximately 2 to 3 minutes. The cell pellet was obtained by centrifugation at 1.000 rpm for 5 minutes. The density of the viable cells was counted by the trypan blue exclusion in a hemocytometer (Neubauer, Assislent, Germany). Cells were then plated in 24-well plate, at a concentration of $50 \times 10^{3} / \mathrm{mL}$ and incubated in a humidifier at $37^{\circ} \mathrm{C}, 5 \% \mathrm{CO}_{2}$ for 72 hours on the surface of the zirconia disks $(n=10)$ from each group. After 1 week, the cells were detached and the density of the viable cells in each well was determined by counting using trypan blue.

\section{Proliferation Assay}

Proliferation was assessed by cell count using trypan blue exclusion dye assay that evaluates cell membrane integrity, and thus is an indicator of cell viability. Cell number was assessed using hemocytometer according to the following formula:

\section{Cells $/ \mathrm{mL}=$ Average number of cells $\times$ Dilution factor $\times$ Volume of suspension $\times 10^{4}$.}

An equal volume of cells and $0.4 \%$ trypan blue solution was mixed and placed under the coverslip atop a hemocytometer grid under the microscope (Olympus, SZ1, Japan). White cells in four large squares were counted as they represent viable cells, whereas blue cells represent dead cells stained by the dye.

\section{Statistical Analysis}

Data were statistically analyzed using SPSS 15.0 (SPSS, Inc., Chicago, Illinois). The one-way ANOVA was used and Tukey's post hoc test for pair-wise comparisons $(\alpha=0.05)$. 


\section{RESULTS}

\section{Surface Characterization}

Statistical analysis showed significant differences in surface roughness values between different tested groups $(p<0.05)$. The ROC reported a significant increase in surface roughness $(2.201 \pm 0.352)$ compared with the other surface treatments and with the control group (Table 2).

- Significant difference was also noted in VHN between the different tested groups; the highest hardness value $(\mathrm{p}<0.05)$ was recorded with the ROC treatment $(1758$ $\pm 16.6)$, followed by the SIE $(983 \pm 12.2)$, LAS $(791 \pm$ 11.4), and the lowest value with AS group (703 \pm 9.7 ; Table 3).

- The atomic force microscopy 3D images showed a nanoporous surface, after zirconia surface treatments, varying from 1 to $1.7 \mu \mathrm{m}$ that indicates surface porosity of different 3D patterns depending on the type of surface treatment (Fig. 1).

- Standard error mean observation showed a regular surface with lines due to the polishing procedure of the AS group. The LAS specimens indicated the presence of micro scratches and very shallow grooves. The ROC specimens reported rough surface with rounded edges, while SIE specimens had a nanoporous surface

Table 2: Mean and SD of the surface roughness values $(\mu \mathrm{m})$ of different test groups

\begin{tabular}{lll}
\hline & Group & Mean \pm SD \\
\hline Ra & AS & $0.475 \pm 0.027$ \\
& ROC & $2.201 \pm 0.352$ \\
& LAS & $1.412 \pm 0.166$ \\
& SIE & $0.830 \pm 0.098$ \\
Rz & AS & $1.884 \pm 0.033$ \\
& ROC & $9.232 \pm 1.061$ \\
& LAS & $5.108 \pm 0.327$ \\
& SIE & $3.037 \pm 0.946$ \\
\hline
\end{tabular}

SD: Standard deviation with valleys and edges without change in surface roughness (Fig. 2).

\section{Cell Adhesion and Proliferation}

The ability of surface-treated disks to alter the proliferation potential of Saos- 2 cells by counting the number of cells after 3 days and 1 week was evaluated. The cell count of Saos- 2 cells cultured alone (control) was maintained steady $\left(51 \times 10^{3}\right)$ after 1 week of culture. However, the cell count after 3 days of cells cultured showed significant differences between the tested groups $(\mathrm{p}<0.05)$; SIE surface-treated reported a significantly higher number of cells ( $64.5 \pm 2.6$ and $53.5 \pm 2.2$ respectively) compared with the other surface-treated groups (ROC and LAS), while no difference was noted with the control AS group. The ROC- and LAS-treated specimens reported a drop in the cell count $(21.5 \pm 1$ and $23 \pm 1.9)$. After 1 week, SIE group reported significant increase in cell count compared with the AS, while ROC and LAS surfacetreated groups showed a very moderate nonsignificant increase in cell count. The level of alkaline phosphatase (ALP) activity was similar for all tested specimens. Cell count, proliferation, and ALP activity are summarized in Table 4.

\section{DISCUSSION}

The results of this study led to the rejection of the null hypothesis that zirconia surface treatments will not

Table 3: Mean and SD of the surface hardness values (VHN) of different test groups

\begin{tabular}{ll}
\hline & Mean $\pm S D$ \\
\hline AS & $703^{\mathrm{a}} \pm 9.7$ \\
ROC & $1758^{\mathrm{b}} \pm 13.6$ \\
LAS & $791^{\mathrm{a}} \pm 11.4$ \\
SIE & $983^{\mathrm{a}} \pm 12.2$ \\
\hline
\end{tabular}

Similar superscripts indicate no significant difference; SD: Standard deviation
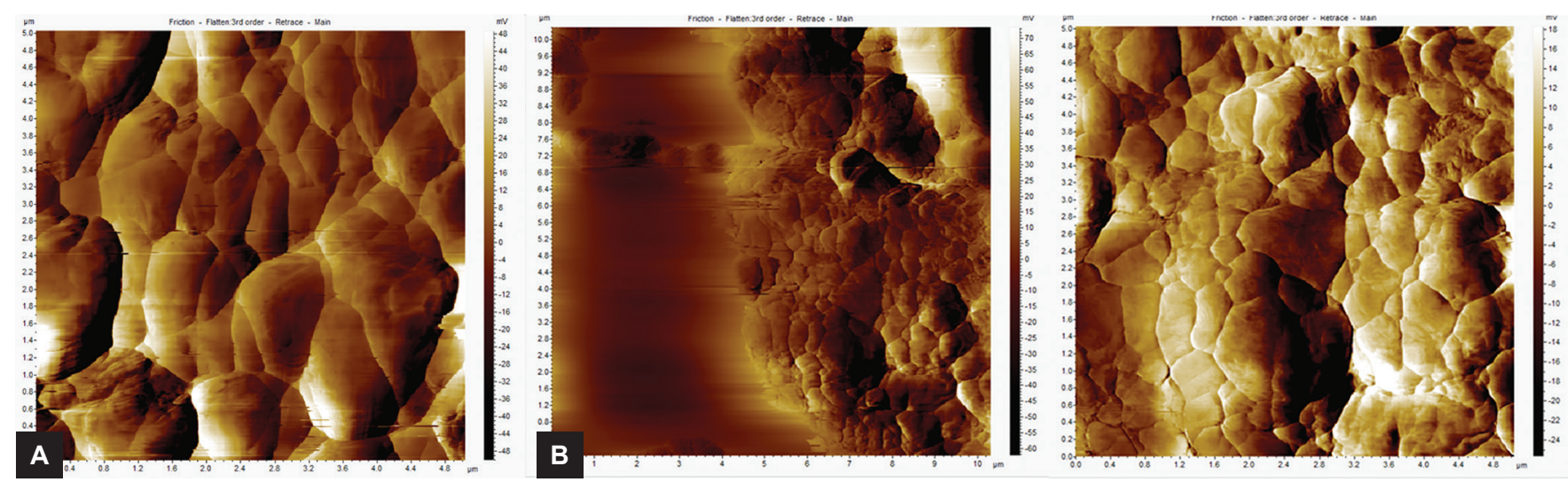

Figs $1 \mathrm{~A}$ and $\mathrm{B}$ : Three-dimensional images showing the difference: $(A)$ Before; and $(B)$ after the zirconia surface treatment; a nanoporous surface is also evident 

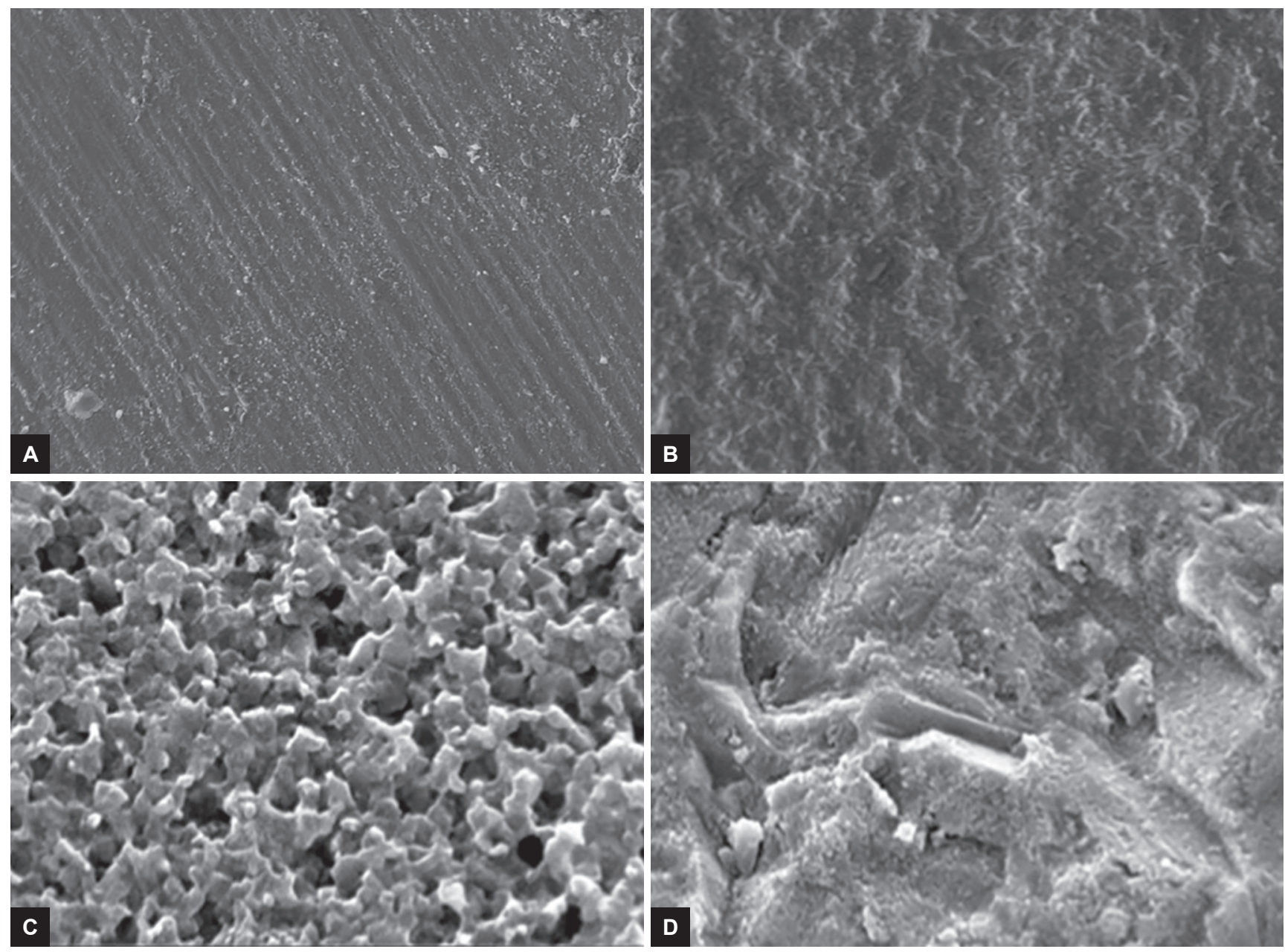

Figs 2A to D: Standard error of the mean observation showing: (A) a regular dense surface with lines due to polishing procedure of the AS group; (B) LAS specimens indicated the presence of micro scratches and very shallow grooves; (C) nanoporous SIE zirconia surface with valleys; and (D) ROC-treated zirconia showing the silica impact on the surface

Table 4: Cell count (mean and SD) on different surfaces of test groups after 3 days and 1 week

\begin{tabular}{llll}
\hline & $\begin{array}{l}\text { Cell count } \\
(3 \text { days })\left(\times 10^{3}\right)\end{array}$ & $\begin{array}{l}\text { Cell count } \\
(7 \text { days })\left(\times 10^{3}\right)\end{array}$ & ALP $(\mathrm{U} / \mathrm{mL})$ \\
\hline AS & $51 \pm 1.4^{\mathrm{a}}$ & $72 \pm 2.1^{\mathrm{a}}$ & $0.19^{\mathrm{a}}$ \\
ROC & $21.5 \pm 1^{\mathrm{b}}$ & $32 \pm 1.4^{\mathrm{b}}$ & $0.21^{\mathrm{a}}$ \\
LAS & $23 \pm 1.9^{\mathrm{b}}$ & $37.5 \pm 1.2^{\mathrm{b}}$ & $0.22^{\mathrm{a}}$ \\
SIE & $53.5 \pm 2.2^{\mathrm{a}}$ & $108 \pm 1.7^{\mathrm{c}}$ & $0.26^{\mathrm{a}}$ \\
\hline
\end{tabular}

Similar superscripts indicate no significant difference; SD: Standard deviation

affect the surface topography and cell proliferation. The clinical success and survival rate of dental implants depend on their surface properties, which initiate and regulate the initial cell response. ${ }^{19}$ Cell adhesion is the main mechanism for proliferation, contributing to osseointegration. ${ }^{18}$

In this study, the significant increase in roughness of the ROC group may be due to the aggressive surface roughening with a silica-coated sandblasting of $110 \mu \mathrm{m}$; this technique can result in the deterioration of the mechanical properties of zirconia. ${ }^{26}$ These results are in accordance with other published papers that showed that surface topography and roughness play a major role in cell adhesion and proliferation. However, highly rough surfaces may play a negative role as fibroblasts show greater affinity for smooth or finely grooved surfaces than for rough ones. ${ }^{27,28}$ Our study showed that after 6 hours of culture, SEM observations revealed only modifications in cell growth on zirconia specimens with no additional surface treatment.

The SIE technique resulted in a nanoroughened $(0.83 \pm 0.09 \mu \mathrm{m})$ surface, while no structural defects were noted. ${ }^{17,26}$ The SIE enhanced cell proliferation and growth when compared with the other surface treatments; this may be due to the new surface topography that is more uniform compared with the others, which helped in initial cell attachment and growth, clearly observed after 7 days that was in accordance with previous published papers. ${ }^{27-29}$

The use of laser energy in zirconia-surface treatment was a subject of interest for researchers. ${ }^{30-33}$ With the objectives of enhancing bonding potential by creating 
a stronger micromechanical interlock, ${ }^{32,33}$ the use of Er, Cr:YSGG laser at $3 \mathrm{~W}$ in the present study resulted in a change of the zirconia surface with a significant roughness increase, while cell growth and proliferation were significantly lower than the AS and the SIE groups, which is in accordance with other published papers. ${ }^{34,35}$ This may be due to the surface topography created by the laser energy and the zirconia absorbing capacity of the wavelength. The increase in temperature and surface destruction due to laser absorption by ceramic creates some porosity on the surface, inducing an augmentation of micromechanical retention. ${ }^{36}$ The evaluation by SEM revealed the presence of microscratches and very shallow grooves that are less aggressive than the ones observed in the ROC-treated specimens. Worthy to mention is that the intensity of the laser treatment is an important factor in the treatment outcome. In this study, specimens were irradiated using $3 \mathrm{~W}$ intensity, while the previous report showed that the behavior of osteoblasts on zirconia treated with laser is intensity-related, and the use of higher input would have enhanced the results. ${ }^{37}$

The particle size influences the roughness values of the abraded specimens. When a size of $110 \mu \mathrm{m}$ of particles was used in the tribochemical treatment, Ra and $\mathrm{Rz}$ achieved the highest values, suggesting that large particles under pressure induced damage on the surface, which is in accordance with published papers. ${ }^{38,39}$ In this study, Ra and Rz were measured to give a better picture of the surface topography, to detect shape of irregularities (valleys and peaks). ${ }^{40}$

The surface hardness (VHN) of the tested groups ranged from 703 to 1758 . There was a significant difference in hardness between the ROC group and all others. The increase in surface hardness was associated with the increase in surface roughness. These findings are in contrary with other papers that reported an increase in surface hardness was associated to decrease in surface hardness. ${ }^{6,41}$

Conventional sandblasting with particles $>100 \mu \mathrm{m}$ causes surface damage and affects the properties of the Y-TZP as reported previously ${ }^{13}$; thus, recommendations for zirconia surface treatment were a combination of sandblasting with small sized particle $(30 \mu \mathrm{m})$ and a chemical conditioner that enhance the bonding to resin. ${ }^{13,17}$ A lowpressure air abrasion method was proposed that reduces surface damage. ${ }^{42}$

The alkaline phosphate activity was used to evaluate the differentiation of cells of the osteogenic lineage and compare the cell activity in different tested groups. ${ }^{43}$ No significant difference in alkaline phosphate activity was noted between all groups, indicating that type of material and surface treatment did not affect the enzyme activity, which is in accordance with other studies. ${ }^{44,45}$
Studies reported that cell attachment on polished (AS) specimens depends on the formation of cytoplasmic extensions as finger-like processes. The spreading and lining of the cells suggest that surface topography is directly involved in the attachment and growth pattern that started after 24 hours. ${ }^{46,47}$

An important factor to be considered is the surface wettability of the zirconia material. A study reported that the hydrophilic surface may enhance cell attachment, ${ }^{48}$ thus preserving zirconia implants in a wet environment to prevent aging. Securing a constant hydrophilic level should open the door to investigations that would impact the long-term prognosis of zirconia implant in combination with other treatment, as ultraviolet photofunctionalization helps in attracting cell on zirconia surface. ${ }^{49}$ Further studies should be conducted to validate the results of this study.

\section{CONCLUSION}

Within the limitations of this study, the following conclusion can be drawn:

- The SIE is a promising surface treatment for zirconia dental implants that significantly enhance cell adhesion and osseointegration.

- Sandblasting the zirconia surface with big sized particles is to be avoided due to the high roughness created that decreases cell proliferation and may create damage to the zirconia structure.

- More surface treatments should be evaluated, especially the ones that are clinically easy-to-use, to make surface treatment accessible to all practitioners using zirconia materials.

\section{REFERENCES}

1. Scarano A, Di Carlo F, Quaranta M, Piattelli A. Bone response to zirconia ceramic implants: an experimental study in rabbits. J Oral Implantol 2003 Feb;29(1):8-12.

2. Sennerby L, Dasmah A, Larsson B, Iverhed M. Bone tissue responses to surface-modified zirconia implants: a histomorphometric and removal torque study in the rabbit. Clin Implant Dent Relat Res 2005 Jun;7(Suppl 1):S13-S20.

3. Möller B, Terheyden H, Açil Y, Purcz NM, Hertrampf K, Tabakov A, Behrens E, Wiltfang J. A comparison of biocompatibility and osseointegration of ceramic and titanium implants: an in vivo and in vitro study. Int J Oral Maxillofac Surg 2012 May;41(5):638-645.

4. Maerten A, Zaslansky P, Mochales C, Traykova T, Mueller WD, Fratzl P, Fleck C. Characterizing the transformation near indents and cracks in clinically used dental yttria-stabilized zirconium oxide constructs. Dent Mater 2013 Feb;29(2): 241-251.

5. Depprich R, Ommerborn M, Zipprich H, Naujoks C, Handschel J, Wiesmann HP, Kübler NR, Meyer U. Behavior of osteoblastic cells cultured on titanium and structured zirconia surfaces. Head Face Med 2008 Dec;4:29. 
6. Piconi C, Maccauro G. Zirconia as a ceramic biomaterial. Biomaterials 1999 Jan;20(1):1-25.

7. Kawai Y, Uo M, Wang Y, Kono S, Ohnuki S, Watari F. Phase transformation of zirconia ceramics by hydrothermal degradation. Dent Mater J 2011 May;30(3):286-292.

8. Hiromoto S, Tsai AP, Sumita M, Hanawa T. Effect of chloride ion on the anodic polarization behavior of the Zr65Al7.5Ni10Cu17.5 amorphous alloy in phosphate buffered solution. Corrosion Sci 2000;42(9):1651-1660.

9. Kim DJ. Effect of $\mathrm{Ta}_{2} \mathrm{O}_{5}, \mathrm{Nb}_{2} \mathrm{O}_{5}$, and $\mathrm{HfO}_{2}$ alloying on the transformability of $\mathrm{Y}_{2} \mathrm{O}_{3}$-stabilized tetragonal $\mathrm{ZrO}_{2}$. J Am Ceramic Soc 1990 Jan;73(1):115-120.

10. Lughi V, Sergo V. Low temperature degradation-aging-of zirconia: a critical review of the relevant aspects in dentistry. Dent Mater 2010 Jan;26:807-820.

11. Dérand P, Dérand T. Bond strength of luting cements to zirconium oxide ceramics. Int J Prosthodont 2000 Mar-Apr; 13(2):131-135.

12. Aboushelib MN, Feilzer AJ, Kleverlaan CJ. Bonding to zirconia using a new surface treatment. J Prosthodont 2010 Jul;19(5):340-346.

13. Oyagüe RC, Monticelli F, Toledano M, Osorio E, Ferrari M, Osorio R. Effect of water aging on microtensile bond strength of dual-cured resin cements to pre-treated sintered zirconiumoxide ceramics. Dent Mater 2009 Mar;25(3):392-399.

14. Liu D, Pow EH, Tsoi JK, Matinlinna JP. Evaluation of four surface coating treatments for resin to zirconia bonding. J Mech Behav Biomed Mater 2014 Apr;32:300-309.

15. Shin YJ, Shin Y, Yi YA, Kim J, Lee IB, Cho BH, Son HH, Seo DG. Evaluation of the shear bond strength of resin cement to Y-TZP ceramic after different surface treatments. Scanning 2014 Sep-Oct;36(5):479-486.

16. Menani LR, Farhat IA, Tiossi R, Ribeiro RF, Guastaldi AC. Effect of surface treatment on the bond strength between yttria partially stabilized zirconia ceramics and resin cement. J Prosthet Dent 2014 Aug;112(2):357-364.

17. Aboushelib MN, Osman E, Jansen I, Everts V, Feilzer AJ. Influence of a nanoporous zirconia implant surface of on cell viability of human osteoblasts. J Prosthodont 2013 Apr;22(3):190-195.

18. Bergemann C, Duske K, Nebe JB, Schöne A, Bulnheim U, Seitz H, Fischer J. Microstructured zirconia surfaces modulate osteogenic marker genes in human primary osteoblasts. J Mater Sci Mater Med 2015 Jan;26(1):5350.

19. Anselme K. Osteoblast adhesion on biomaterials. Biomaterials 2000 Apr;21(7):667-681.

20. Drosse I, Volkmer E, Capanna R, De Biase P, Mutschler W, Schieker M. Tissue engineering for bone defect healing: an update on a multi-component approach. Injury 2008 Sep;39(Suppl 2):S9-S20.

21. Lüthen F, Lange R, Becker P, Rychly J, Beck U, Nebe JG. The influence of surface roughness of titanium on beta1-and beta3integrin adhesion and the organization of fibronectin in human osteoblastic cells. Biomaterials 2005 May;26(15):2423-2440.

22. Wenz HJ, Bartsch J, Wolfart S, Kern M. Osseointegration and clinical success of zirconia dental implants: a systematic review. Int J Prosthodont 2008 Jan-Feb;21(1):27-36.

23. Yamashita D, Machigashira M, Miyamoto M, Takeuchi H, Noguchi K, Izumi Y, Ban S. Effect of surface roughness on initial responses of osteoblast-like cells on two types of zirconia. Dent Mater J 2009 Jul;28(4):461-470.

24. Borghetti P, De Angelis E, Caldara G, Corradi A, Cacchioli A, Gabbi C. Adaptive response of osteoblasts grown on a titanium surface: morphology, cell proliferation and stress protein synthesis. Vet Res Commun 2005 Aug;29(Suppl 2):221-224.

25. Lincks J, Boyan BD, Blanchard CR, Lohmann CH, Liu Y, Cochran DL, Dean DD, Schwartz Z. Response of MG63 osteoblast-like cells to titanium and titanium alloy is dependent on surface roughness and composition. Biomaterials 1998 Dec;19(23):2219-2232.

26. Aboushelib MN, Kleverlaan CJ, Feilzer AJ. Selective infiltration-etching technique for a strong and durable bond of resin cements to zirconia-based materials. J Prosthet Dent 2007 Nov;98(5):379-388.

27. Chehroudi B, Gould TR, Brunette DM. A light and electron microscopic study of the effects of surface topography on the behavior of cells attached to titanium-coated percutaneous implants. J Biomed Mater Res 1991 Mar;25(3):387-405.

28. Könönen M, Hormia M, Kivilahti J, Hautaniemi J, Thesleff I. Effect of surface processing on the attachment, orientation, and proliferation of human gingival fibroblasts on titanium. J Biomed Mater Res 1992 Oct;26(10):1325-1341.

29. Ewais $\mathrm{OH}, \mathrm{Al}$ Abbassy F, Ghoneim MM, Aboushelib MN. Novel zirconia surface treatments for enhanced osseointegration: laboratory characterization. Int J Dent 2014 Sep;2014:203940.

30. Liu D, Matinlinna JP, Tsoi JK, Pow EH, Miyazaki T, Shibata Y, Kan CW. A new modified laser pretreatment for porcelain zirconia bonding. Dent Mater 2013 May;29(5):559-565.

31. Kara O, Kara HB, Tobi ES, Ozturk AN, Kilic HS. Effect of various lasers on the bond strength of two zirconia ceramics. Photomed Laser Surg 2015 Feb;33(2):69-76.

32. Ghasemi A, Kermanshah H, Ghavam M, Nateghifard A, Torabzadeh H, Nateghifard A, Zolfagharnasab K, Ahmadi H. Effect of Er,Cr:YSGG laser treatment on microshear bond strength of zirconia to resin cement before and after sintering. J Adhes Dent 2014 Aug;16(4):377-382.

33. Kirmali O, Kustarci A, Kapdan A, Er K. Efficacy of surface roughness and bond strength of Y-TZP zirconia after various pre-treatments. Photomed Laser Surg 2015 Jan;33(1):15-21.

34. Zeidan LC, Esteves CM, Oliveira JA, Brugnera A Jr, Cassoni A, Rodrigues JA. Effect of different power settings of Er,Cr:YSGG laser before or after tribosilicatization on the microshear bond strength between zirconia and two types of cements. Lasers Med Sci 2017 Oct.

35. Dede DÖ, Yenisey M, Rona N, Öngöz Dede F. Effects of laser treatment on the bond strength of differently sintered zirconia ceramics. Photomed Laser Surg 2016 Jul;34(7):276-283.

36. Akyil MS, Uzun IH, Bayindir F. Bond strength of resin cement to yttrium-stabilized tetragonal zirconia ceramic treated with air abrasion, silica coating, and laser irradiation. Photomed Laser Surg 2010 Dec;28(6):801-808.

37. Soares RD, Rodrigues JA, Cassoni A, Cruz A, Simões CO, Pasqua-Neto JD, Gehrke SA, Blay A, Cesar PF, Shibli JA. In vitro behavior of osteoblasts on zirconia after different intensities of erbium, chromium-doped: Yttrium, scandium, gallium, and garnet-laser irradiation. J Craniofac Surg 2016 May;27(3):784-788.

38. Queiroz JR, Paulo GP, Özcan M, Nogueira L Jr. Effect of airborne particle abrasion protocols on surface topography of Y-TZP ceramic. Cerâmica 2012 Apr-Jun;58(346):253-261.

39. Serkan S, Onjen T, Gamze A. Basic properties and types of zirconia: an overview. World J Stomatol 2013 Aug;2(3): $40-47$. 
40. Tanaka R, Fujishima A, Shibata Y, Manabe A, Miyazaki T. Cooperation of phosphate monomer and silica modification on zirconia. J Dent Res 2008 Jul;87(7):666-670.

41. Pittayachawan P, McDonald A, Petrie A, Knowles JC. The biaxial flexural strength and fatigue property of Lava Y-TZP dental ceramic. Dent Mater 2007 Aug;23(8):1018-1029.

42. Hempel U, Hefti T, Kalbacova M, Wolf-Brandstetter C, Dieter P, Schlottig F. Response of osteoblast-like SAOS-2 cells to zirconia ceramics with different surface topographies. Clin Oral Implants Res 2010 Feb;21(2):174-181.

43. Boyan BD, Schwartz Z, Hambleton JC. Response of bone and cartilage cells to biomaterials in vivo and in vitro. J Oral Implantol 1993;19(2):116-122.

44. Kohal RJ, Baechle M, Han JS, Hueren D, Huebner U, Butz F. In vitro reaction of human osteoblasts on aluminatoughened zirconia. Clin Oral Implants Res 2009 Nov;20(11): 1265-1271.
45. Le Guehennec L, Lopez-Heredia MA, Enkel B, Weiss P, Amouriq Y, Layrolle P. Osteoblastic cell behaviour on different titanium implant surfaces. Acta Biomater 2008 May;4(3):535-543.

46. Piattelli A, Pontes AE, Degidi M, Iezzi G. Histologic studies on osseointegration: soft tissues response to implant surfaces and components. A review. Dent Mater 2011 Jan;27(1):53-60.

47. Mendonça DB,MiguezPA,MendonçaG, YamauchiM,AragãoFJ, Cooper LF. Titanium surface topography affects collagen biosynthesis of adherent cells. Bone 2011 Sep;49(3):463-472.

48. Watanabe H, Saito K, Kokubun K, Sasaki H, Yoshinari M. Change in surface properties of zirconia and initial attachment of osteoblastlike cells with hydrophilic treatment. Dent Mater J 2012 Jun;31(5):806-814.

49. Tuna T, Wein M, Altmann B, Steinberg T, Fischer J, Att W. Effect of ultraviolet photofunctionalisation on the cell attractiveness of zirconia implant materials. Eur Cell Mater 2015 Jan;29:82-94. 